\title{
KAJIAN TRANSFORMASI INDEKS VEGETASI CITRA SATELIT SENTINEL-2A UNTUK ESTIMASI PRODUKSI DAUN KAYU PUTIH MENGGUNAKAN LINEAR SPECTRAL MIXTURE ANALYSIS
}

\author{
Lilik Norvi Purhartanto ${ }^{1 *}$, Projo Danoedoro ${ }^{2}$, Pramaditya Wicaksono ${ }^{2}$ \\ ${ }^{1}$ Program Studi Penginderaan Jauh, Fakultas Geografi, Universitas Gadjah Mada, Yogyakarta, 55281 \\ ${ }^{2}$ Fakultas Geografi, Universitas Gadjah Mada, Yogyakarta, 55281 \\ *Email : liliknorvi.p@gmail.com
}

\begin{abstract}
ABSTRAK
A forest plantation area of Melaleuca cajuputi at BDH Karangmojo, BKPH Yogyakarta are 2,325.20 ha. One of the efforts to keep its sustainability is to plan the target and realization of cajuputi leaf production considerwith forest condition. Advances in remote sensing technology can be an alternative in estimating the cajuputi leaf production on large areas with an efficient time and high accuracy and able to analyze the quality of cajuputi. This study aims to examine Sentinel-2A capabilities through a relationship model of some vegetation indices integrated with vegetative factors on the production to obtain estimates of leaf production, map and test the estimation model accuracy. The method used is to classify objects in pixels with Linear Spectral Mixture Analysis and build relationship between age, number of plants and vegetation index with cajuputi leaf production. The results showed that the unmixing method has $99,66 \%$ accuracy in classifying pixels into the fraction of cajuputi. MERIS Terrestrial Chlorophyll Index of unmixing cajuputi fraction simultaneously with age and number of plants has the highest correlation with value of $r=0,668$ to the production and modeled in mapping the estimated cajuputi leaf production at the research location with Standard Error of Estimate is 0,183.
\end{abstract}

Keywords: vegetation index, Linear Spectral Mixture Analysis, production estimation, Melaleuca cajuputi

\section{PENDAHULUAN}

\section{Latar Belakang}

Salah satu hasil hutan bukan kayu unggulan di Daerah Istimewa Yogyakarta adalah daun kayu putih dengan produk turunan berupa minyak kayu putih yang telah menyumbangkan 3\% kebutuhan nasional dari produksi dalam negeri (Kartikawati et al., 2014). Hasil inventarisasi tahun 2012 luas hutan tanaman kayu putih yang ada di BDH Karangmojo mencapai $2.325,20$ ha. Produksi daun kayu putih mengalami penurunan dari tahun 2014 sampai dengan 2017. Optimalisasi produksi perlu penentuan target produksi daun kayu putih yang tepat dengan memperhatikan potensi dan kelestarian tanaman. Estimasi produksi merupakan salah satu upaya untuk mengetahui potensi produksi kedepan dan merupakan hal yang penting bagi keberhasilan pengusahaan tanaman secara ekonomis (Wiratmoko, 2014). 
Konsep pengaturan berdasarkan pendugaan hasil sebaiknya dilakukan berdasarkan pada data dan informasi akhir dari sumberdaya serta pendugaan nilai maksimum pemanenan lestari (Vanclay, 1995). Perkembangan penginderaan jauh dan sistem informasi geografis dapat memberikan data spesifik yang tidak dapat diperoleh dari sumber data lainnya dan dapat digunakan untuk mengumpulkan data tanpa banyak kerja lapangan dengan hasil yang lebih cepat dan akurat. Tujuan praktis dalam bidang kehutanan dapat dilakukan dengan cara mengawinkan data penginderaan jauh, data lapangan, dan uji silang hasil analisis citra dengan sampel lapangan (Howard, 1996). Berdasarkan kemampuannya tersebut maka dapat dikatakan bahwa penginderaan jauh mampu digunakan untuk melengkapi, memperbaiki, atau mengurangi pekerjaan lapangan. Salah satu keunggulan penginderaan jauh adalah mampu menyediakan data informasi permukaan bumi yang relatif lengkap dalam waktu singkat dan dapat menjangkau wilayah luas tanpa menyentuh langsung objek kajian serta dapat digunakan memperbarui database di berbagai bidang secara berkala (Purwadhi et al., 2009).

Saat ini terdapat pilihan citra penginderaan jauh yang memiliki resolusi tinggi dengan saluran spektral lebih banyak seperti citra Sentinel-2A. Citra Sentinel-2A memiliki instrument multispektral dengan 13 saluran spektral yang terdiri dari saluran cahaya tampak (visible), inframerah dekat $(N I R)$, dan gelombang pendek inframerah (SWIR). Penambahan saluran vegetation red-edge $(703,9-782,5 \mathrm{~nm})$ dan narrow $N I R(864,8 \mathrm{~nm})$ digunakan untuk mempertajam studi vegetasi. Penggunaan citra Sentinel-2A dalam estimasi produksi daun kayu putih bertujuan mengetahui pengaruh indeks vegetasi yang menggunakan saluran visible, NIR, SWIR, dan red-edge terhadap hasil estimasi produksi.

\section{Tujuan}

Penelitian ini bertujuan untuk mengkaji kemampuan citra Sentinel-2A melalui model hubungan beberapa indeks vegetasi yang diintegrasikan dengan faktor vegetatif (umur dan jumlah tanaman) terhadap produksi daun kayu putih untuk mendapatkan estimasi produksi daun kayu putih, serta memetakan dan menguji akurasi estimasi produksi daun kayu putih hasil pemodelan menggunakan citra Sentinel-2A.

\section{Tinjauan Pustaka}

Penerapan data penginderaan jauh yang berkelanjutan terhadap pertumbuhan tanaman yang dikombinasikan dengan indeks vegetasi menunjukkan kondisi pertumbuhan tanaman secara temporal dan spasial serta telah terbukti merupakan salah satu alat dalam skala lapang 
mampu mengestimasi produksi suatu tanaman (Qi et al., 1993; Wójtowicz etat., 2016). Kajian tentang vegetasi dengan citra penginderaan jauh banyak memanfaatkan transformasi beberapa saluran yang disebut indeks vegetasi. Indeks vegetasi yang memanfaatkan saluran hijau (green), merah (red), red-edge, dan inframerah dekat (NIR) merupakan indeks vegetasi yang sensitif terhadap kandungan klorofil tanaman (Daughtry et al., 2000; Haboudane et al., 2002). Evaluasi informasi spektral yang dibutuhkan untuk pemetaan Leaf Area Index dengan pendekatan Look up Table dan Artificial Neural Network menunjukkan bahwa panjang gelombang NIR dan red-edge memberikan informasi yang paling relevan untuk LAI (Richter et al., 2012).

Pada daun dengan kandungan klorofil yang tinggi, minimal sensitivitas terhadap variasi pigmen diamati pada $675 \mathrm{~nm}$ dan Standar Deviasi maksimal antara 550-560 dan 700-710 nm. Model spektral tersebut dapat berfungsi sebagai indikator tahap awal penuaan daun (Gitelson et al., 1994). Penelitian Gitelson et al. (2003) untuk mengetahui pola pantulan spektral kandungan klorofil dan mengestimasi klorofil daun menunjukkan bahwa dalam rentang spektral dari 520-585 nm dan 695-740 nm terkait erat dengan kandungan klorofil total dalam daun semua spesies dan semakin meningkatkan akurasi estimasi klorofil. Indeks dengan rentang spektral [(R750-800) / (R695-740) -1] dan [(R750-800) / (R 520-585) -1], adalah prediktor klorofil terbaik dengan RMSE $<39 \mu \mathrm{mol} / \mathrm{m}^{2}$.

Rondeaux et al. (1996) menguji dan membandingkan sensitivitas indeks vegetasi untuk efek latar belakang tanah. Formulasi umum indeks SAVI dengan formula VI $=(\mathrm{NIR}-\mathrm{R}) /$ $(\mathrm{NIR}+\mathrm{R}+\mathrm{X})$ diteliti lebih lanjut dimana nilai parameter $\mathrm{X}$ sangat penting dalam minimalisasi efek tanah. Nilai $\mathrm{X}=0,16$ ditemukan sebagai nilai yang optimal. Rock et al. (1986) telah membuktikan bahwa rasio saluran inframerah pada indeks tingkat kelembaban daun (Moisture Stress Index /MSI) yaitu 1,65/1,23 $\mu \mathrm{m}$ atau 1,65/0,83 $\mu \mathrm{m}$ berkorelasi baik dengan kerusakan hutan, dan citra yang terbentuk menggunakan rasio ini bersama dengan saluran tampak dan inframerah membuat area hutan dengan tingkat kerusakan tinggi atau rendah menjadi mudah terlihat. Hardisky et al. (1983) telah memasukkan indeks saluran inframerah ke dalam analisis parameter biomassa karena memiliki potensi sensitivitas terhadap kadar air. Saluran inframerah tengah $(1,55-1,75 \mu \mathrm{m})$ yang peka terhadap kelembaban dan saluran inframerah dekat $(0,76-0,90 \mu \mathrm{m})$ yang peka terhadap struktur daun mampu memberikan informasi tambahan tentang jaringan daun yang mati.

Saluran red-edge pada citra Sentinel-2A penting untuk pengambilan dan pemantauan LAI dan secara signifikan memperbaiki keakuratan estimasi kandungan klorofil (Delegido et 
al., 2011). Sejalan dengan Dash et al. (2004) bahwa melalui penginderaan jauh, band rededge telah berhasil digunakan untuk mengestimasi kandungan klorofil tajuk vegetasi. Penggunaan citra Sentinel-2 dan 3 dalam memperkirakan klorofil dan kandungan nitrogen pada tanaman jagung, kacang kedelai, kentang, dan rumput menunjukkan bahwa Red-Edge Chlorophyll Index (CIRE), Green Chlorophyll Index (CIGreen), dan Medium Resolution Imaging Spectrometer Terrestrial Chlorophyll Index (MTCI) memiliki tingkat akurasi yang terbaik serta pentingnya saluran red-edge terutama Sentinel-2A untuk aplikasi pertanian (Clevers et al., 2013). Hubungan yang signifikan antara kandungan klorofil kanopi dan LAI terhadap Inverted Red-Edge Chlorophyll Index (IRECI) dan Normalized Difference Vegetation Index (NDVI) sedangkan Sentinel-2 Red-Edge Position (S2REP) dan MTCI memiliki korelasi terbaik untuk analisis Leaf Chlorophyll Concentration (LCC) (Frampton et al., 2013). Uji kemampuan indeks vegetasi terkait analisis klorofil dalam mengestimasi penyerapan radiasi aktif proses fotosintesis (Fraction of Absorbed Photosynthetically Active Radiation / FPAR) pada tanaman gandum dan jagung menggunakan data Sentinel-2A menunjukkan bahwa indeks vegetasi Simple Ratio (SR) yang dimodifikasi menggunakan saluran Vegetation Red-Edge (saluran 5 dan 6) memiliki korelasi terbaik dengan FPAR dan relatif peka terhadap struktur kanopi (Dong et al., 2015). Penelitian untuk mengetahui kecocokan panjang gelombang red-edge citra Sentinel-2A dalam menggambarkan tingkat keparahan kebakaran lahan menunjukkan bahwa indeks vegetasi menggunakan saluran rededge yaitu Simple Ratio Red-Edge (SRRE), CIRE, dan Red-Edge Normalized Difference Vegetation Index (RENDVI) mampu membedakan empat tingkat keparahan kebakaran (Fernandez-Manso et al., 2016). Pentingnya saluran red-edge dan SWIR untuk pemetaan vegetasi ditunjukkan dengan tingginya kemampuan Sentinel-2A untuk menghasilkan peta penutupan lahan dengan akurasi $65 \%$ untuk jenis pohon dan $76 \%$ untuk jenis tanaman semusim (Immitzer et al., 2016).

Spectral Mixture Analysis menyediakan suatu strategi kuantitatif dalam mempelajari citra multispektral. Metode ini telah dipergunakan untuk melakukan deteksi subpiksel serta klasifikasi dari piksel campuran pada citra hasil penginderaan jauh. Pada Linear Spectral Mixture Analysis, nilai spektral pada piksel dimodelkan sebagai kombinasi linear dari pantulan setiap endmember, yang besarnya sesuaidengan persentasi tutupan dari setiap endmember di lapangan. Endmember merupakan komponen fisik dasar yang secara fundamental dianggap tidak bercampur dengan komponen yang lainnya dalam sebuah piksel. Asumsi mengenai model linear di perlukan agar setiap komponen dapat dengan mudah diatur 
dan dipisahkan dari sebuah piksel. Konfigurasi ini dapat mereduksi banyaknya nilai pantulan dari campuran setiap endmember yang terdeteksi pada skala panjang gelombang radiasi elektromagnetik (Klein et al., 1999).

Setiap objek di permukaan bumi yang terekam oleh satelit penginderaan jauh memantulkan atau memancarkan gelombang elektromagnetik yang juga disebut dengan nilai kecerahan (Brightness Value). Objek-objek tersebut dibentuk dalam piksel-piksel pada citra satelit yang merupakan bagian terkecil dari suatu citra. Satelit Sentinel-2A yang memiliki resolusi spasial 10; 20; dan $60 \mathrm{~m}$ dan meliputi wilayah yang heterogen, tentunya dalam setiap satu pikselnya tidak hanya terdiri dari satu objek saja, sehingga terdapat kemungkinan bahwa dalam satu piksel citra terdapat campuran dari beberapa objek (spectral mixing). Penggunaan LSMA dapat menentukan proporsi spasial objek-objek yang terdapat dalam satu piksel.

\section{METODE PENELITIAN}

\section{Lokasi Penelitian}

Penelitian ini dilakukan di Bagian Daerah Hutan Karangmojo, Balai KPH Yogyakarta yang terletak diantara $110^{\circ} 35^{\prime} 15,91^{\prime \prime}-110^{\circ} \quad 42^{\prime} 42,7^{\prime \prime}$ LS dan $07^{\circ} 52^{\prime} 4,11^{\prime \prime}-08^{\circ}$ 02'14,89" BT. Secara administrasi sebagian besar terletak di Kecamatan Karangmojo dan Nglipar, Kabupaten Gunungkidul, Daerah Istimewa Yogyakarta.

\section{Bahan dan Alat}

Penelitian menggunakan citra multispektral Sentinel-2A perekaman tanggal 20 Juni 2017 dengan band yang digunakan adalah band dengan resolusi spasial $10 \mathrm{~m}$ resampling $20 \mathrm{~m}$ dan resolusi spasial $20 \mathrm{~m}$, yaitu band green, red, red-edge, NIR, narrow NIR, dan SWIR, DEM ALOS Palsar resolusi 12,5 m, dan citra Google Earth perekaman 17 Mei 2017. Alat yang digunakan antara lain pita ukur, tali ukuran 20 m, GPS, kamera, timbangan, alat tulis, tally sheet, komputer dan software-nya. 


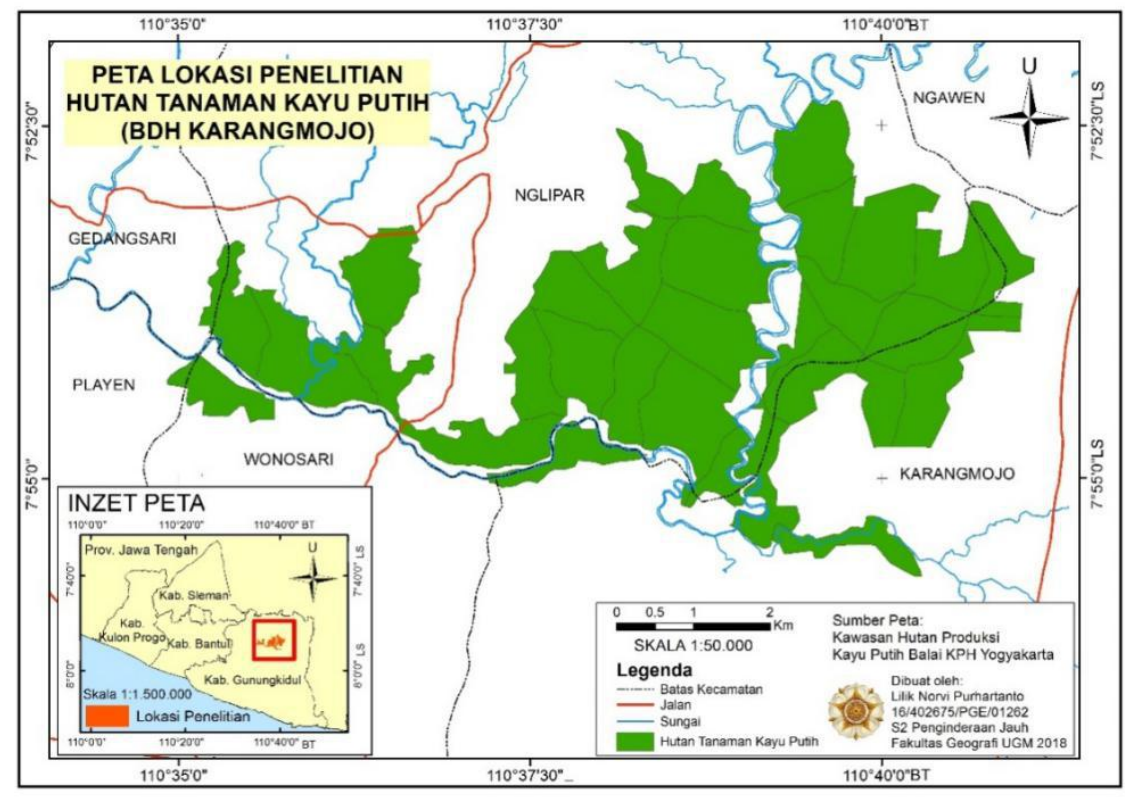

Gambar1.Peta lokasi penelitian di Gunungkidul, DIY

\section{Pengambilan Sampel}

Lokasi pengambilan sampel ditentukan berdasarkan peta sebaran tanaman kayu putih pada lokasi penelitian. Sampel lapangan diambil dengan metode stratified random sampling sebanyak 60 sampel. Jumlah sampel terbagi menjadi 40 sampel untuk membuat model dan 20 sampel untuk uji akurasi model. Pada setiap plot sampel diukur berat (produksi) daun kayu putih, jumlah dan umur tanaman.

Ukuran plot sampel mengacu pada Standar Nasional Indonesia (SNI) 7724:2011 (Badan Standarisasi Nasional, 2011) untuk pengamatan tingkatan pertumbuhan vegetasi pohon ukuran plot sampel lapangan adalah $20 \times 20 \mathrm{~m}$. Secara ekologis penting membedakan tingkatan vegetasi menurut bentuk dan pertumbuhannya yaitu semai, pancang, tiang, dan pohon, sehingga perlu membuat batasan sampel untuk berbagai tingkatan tersebut, yaitu untuk pohon ukuran plot 20 × 20 m (Soerianegara et al., 1998).

\section{Pengolahan Citra}

Citra Sentinel-2A telah terkoreksi radiometrik dalam bentuk nilai TOA reflectance (Top of Atmosphere) sehingga untuk proses koreksi selanjutnya adalah koreksi atmosferik untuk merubah nilai piksel citra dari TOA reflectance menjadi at surface reflectance dengan metode Dark Object Subtraction (DOS) (Chavez, 1996). Selain koreksi atmosferik juga dilakukan koreksi terhadap pengaruh topografi pada citra untuk lebih meningkatkan ketelitian 
nilai spektral dalam merepresentasikan objek di lapangan dikarenakan kondisi daerah penelitian yang agak heterogen topografinya. Metode koreksi topografi yang digunakan adalah The Cosine Correction (Teillet et al., 1982) yang telah terbukti dapat mengurangi variabilitas nilai spektral yang disebabkan oleh ketidaksamaan sudut datang sinar pada satu kondisi perekaman citra akibat perbedaan kemiringan dan aspek lereng (Murti, 2014). Citra Sentinel-2A yang digunakan dalam penelitian ini tidak dilakukan koreksi geometrik, dikarenakan citra Sentinel-2A yang digunakan adalah level 1C yang telah terkoreksi geometrik (European Space Agency, 2015).

\section{Pengolahan Linear Spectral Mixture Analysis}

Mengestimasi produksi daun kayu putih agar lebih akurat digunakan metode Linear Spectral Mixture Analysis (LSMA) dengan mempersentasekan komposisi penyusun dalam satu piksel untuk memperoleh fraksi kayu putih. Pada proses LSMA asumsi terpenting yaitu spectral signature endmember setiap piksel adalah linier (Asis and Omasa, 2007; Somers et al., 2011). Model LSMA harus memenuhi dua kondisi utama, yaitu pertama proporsi semua fraksi endmember dalam satu piksel harus sama dengan 1.

$$
\Sigma_{i=1}^{N} F_{i}=F_{1}+F_{2}+\ldots+F_{N}=1
$$

Kedua, setiap saluran spektral nilai BV $\lambda$ setiap piksel merupakan jumlah BV dari piksel murni setiap endmember dikalikan bobot fraksi setiap endmember ditambah nilai error.

$$
B V \lambda=F_{1} B V \lambda_{.1}+F_{2} B V \lambda_{.2}+\ldots+F_{N} B V \lambda_{. N}+E \lambda
$$

Tahapan analisis Linear Spectral Mixture Analysis yaitu:

\section{Minimum Noise Fraction (MNF)}

Proses MNF bertujuan untuk menghasilkan citra bebas gangguan dan endmember dengan kualitas baik. Transformasi MNF mengurangi gangguan dan korelasi antar saluran. Identifikasi gangguan dilakukan menggunakan nilai eigen.

\section{Pixel Purity Index (PPI)}

Penentuan nilai piksel murni dari setiap endmember dilakukan melalui proses PPI. Piksel murni tersebut adalah piksel yang mengandung nilai kecerahan (BV) objek (endmember) yang berhubungan dengan frekuensi berapa kali piksel terekam secara ekstrem. 


\section{Penentuan endmember}

Endmember adalah objek yang dipisahkan dari objek-objek lainnya. Endmember yang akan dipisahkan adalah tanaman kayu putih, tanaman non-kayu putih, lapisan kedap air (batuan), dan lahan terbuka. Empat komponen tersebut dianggap mewakili objek di hutan.

\section{Implementasi LSMA}

Hasil implementasi LSMA adalah persentase fraksi setiap endmember atau objek dalam satu piksel dan citra kesalahan piksel semua endmember yang ditinjukkan dalam citra RMSE. Berdasarkan sebaran piksel tersebut, maka diketahui piksel-piksel yang memiliki perentase endmember murni dan campuran dengan objek lain. Klasifikasi LSMA dieksekusi menggunakan constrain unmixing yang memberi batas bahwa setiap piksel mempunyai jumlah fraksi sama dengan satu (Fauziana, 2016).

\section{Transformasi Indeks Vegetasi}

Hasil penelitian sebelumnya menunjukkan bahwa indeks vegetasi yang menggunakan band green, red, red-edge dan NIR merupakan indeks vegetasi yang sensitif terhadap LAI, kandungan klorofil dan nitrogen, struktur kanopi serta tingkat keparahan kebakaran lahan (Hardisky et al., 1983; Rock et al., 1986; Gitelson et al., 1994; Rondeaux et al., 1996; Daughtry et al., 2000; Haboudane et al., 2002; Gitelson et al., 2003; Richter et al., 2012; Delegido et al., 2011; Clevers et al., 2013; Frampton et al., 2013; Dong et al., 2015; Fernandez-Manso et al., 2016). Selain band yang sering digunakan dalam penelitian sebelumnya juga digunakan band SWIR seperti dilakukan Immitzer et al. (2016) dalam pemetaan vegetasi. Beberapa indeks vegetasi yang digunakan disajikan pada Tabel 1.

Tabel 1.Indeks vegetasi yang digunakan dalam penelitian.

\begin{tabular}{|c|c|c|c|c|}
\hline Indeks Vegetasi & $\begin{array}{c}\text { Singkata } \\
\mathrm{n}\end{array}$ & \multicolumn{2}{|c|}{ Rumus } & Referensi \\
\hline Simple Ratio Red-Edge & SR RE & NIR/Red-Edge & $\frac{R_{750}}{R_{705}}$ & $\begin{array}{c}\text { Gitelson and } \\
\text { Merzlyak (1994) }\end{array}$ \\
\hline Chlorophyll Index Red-Edge & CI RE & $\begin{array}{c}(\mathrm{NIR} / \text { Red-Edge })- \\
1\end{array}$ & $\left(\frac{R_{783}}{R_{705}}\right)-1$ & $\begin{array}{l}\text { Gitelson et al. } \\
\quad(2003)\end{array}$ \\
\hline Chlorophyll Index Green & $\begin{array}{c}\text { CI } \\
\text { GREEN }\end{array}$ & (NIR/Green) - 1 & $\left(\frac{R_{783}}{R_{560}}\right)-1$ & $\begin{array}{l}\text { Gitelson et al. } \\
\quad(2003)\end{array}$ \\
\hline $\begin{array}{l}\text { MERIS Terrestrial } \\
\text { Chlorophyll Index }\end{array}$ & MTCI & $\begin{array}{c}\mathrm{NIR}-R e d-E d g e) / \\
(\text { Red-Edge-Red })\end{array}$ & $\frac{R_{740}-R_{705}}{R_{705}-R_{655}}$ & $\begin{array}{c}\text { Dash and Curran } \\
(2004)\end{array}$ \\
\hline $\begin{array}{l}\text { Red-Edge Normalized } \\
\text { Difference Vegetation Index }\end{array}$ & RENDVI & $\begin{array}{c}\text { (NIR-Red-Edge) / } \\
(\mathrm{NIR}+\text { Red-Edge })\end{array}$ & $\frac{R_{740}-R_{705}}{R_{740}+R_{705}}$ & $\begin{array}{c}\text { Gitelson and } \\
\text { Merzlyak (1994) }\end{array}$ \\
\hline $\begin{array}{l}\text { Optimized Soil Adjusted } \\
\text { Vegetation Index }\end{array}$ & OSAVI & $\begin{array}{c}(\mathrm{NIR}-\mathrm{Red}) / \\
(\mathrm{NIR}+\text { Red }+0.16)\end{array}$ & $\frac{\left(R_{800}-R_{670}\right)}{\left(R_{800}+R_{670}+0,16\right)}$ & $\begin{array}{c}\text { Rondeaux et al. } \\
\text { (1996) }\end{array}$ \\
\hline
\end{tabular}


Lilik Norvi Purhartanto, Projo Danoedoro, Pramaditya Wicaksono, Kajian Transformasi Indeks Vegetasi Citra Satelit Sentinel-2A Untuk Estimasi Produksi Daun Kayu Putih Menggunakan Linear Spectral Mixture Analysis

\begin{tabular}{lcccc}
\hline Moisture Stress Index & MSI & (SWIR/NIR) & $\left(\frac{R_{1650}}{R_{830}}\right)$ & Rock et al. (1986) \\
\hline $\begin{array}{l}\text { Normalized Difference } \\
\text { Infrared Index }\end{array}$ & NDII & $\begin{array}{c}\text { (NIR-SWIR) } / \\
\text { (NIR+SWIR) }\end{array}$ & $\frac{\left(R_{760 \text { to } 900}-R_{1550 \text { to } 1750}\right)}{\left(R_{760 \text { to } 900}+R_{1550 \text { to } 1750}\right)}$ & $\begin{array}{c}\text { Hardisky et al. } \\
(1983)\end{array}$ \\
\hline
\end{tabular}

Nilai indeks vegetasi hasil transformasi masih merupakan nilai dari piksel campuran, sehingga untuk mengetahui nilai indeks vegetasi kayu putih saja perlu menggunakan formula lain yang diadaptasi dari Brown (2001). Melalui proses LSMA persamaan sebagai berikut:

$$
\begin{gathered}
I V_{\text {piksel }}=\mathrm{f}_{\text {kayu putih }} * I V_{\text {kayu putih }}+\mathrm{f}_{\text {vegetasi non-kayu putih }} * \mathrm{IV}_{\text {vegetasi non-kayu putih }}+ \\
\mathrm{f}_{\text {lapisan kedap air }} * I V_{\text {lapisan kedap air }}+\mathrm{f}_{\text {lahan terbuka }} * \mathrm{IV}_{\text {lahan terbuka }}+\mathcal{E}
\end{gathered}
$$

dimana: $\mathrm{IV}_{\text {piksel }}$ : nilai indeks vegetasi piksel murni

$$
\begin{array}{ll}
\mathrm{f}_{\mathrm{s}} & : \text { fraksi endmember } \\
\varepsilon & : \text { RMSE }
\end{array}
$$

Berdasarkan persamaan di atas maka dapat diturunkan persamaan untuk mencari indeks vegetasi kayu putih sebagai berikut dengan indeks vegetasi setiap endmember dipilih pada objek murni:

$$
\begin{aligned}
I V_{\text {kayu putih }}= & I V_{\text {piksel }}-\left(f_{\text {vegetasi non-kayu putih }} * I V_{\text {vegetasi non-kayu putih }}\right)- \\
& \left(f_{\text {lapisan kedap air }} * I V_{\text {lapisan kedap air }}\right)-\left(f_{\text {lahan terbuka }} * I V_{\text {lahan terbuka }}\right)-\mathcal{E}
\end{aligned}
$$

\section{Analisis Data}

Analisis statistik yang digunakan untuk mengetahui hubungan beberapa indeks vegetasi, umur, dan jumlah tanaman terhadap produksi daun kayu putih adalah analisis korelasi dan regresi. Koefisien korelasi menunjukkan derajat kekuatan hubungan nilai indeks vegetasi, umur, dan jumlah tanaman terhadap produksi daun kayu putih hasil pengukuran berat sampel daun tanaman di lapangan. Nilai indeks vegetasi sebagai variabel bebas $\left(x_{1}\right)$, umur sebagai variabel bebas $\left(x_{2}\right)$, jumlah tanaman sebagai variabel bebas $\left(x_{3}\right)$, dan produksi daun kayu putih sebagai variabel terikat $(y)$. Sebelum uji korelasi dan regresi, dilakukan uji normalitas untuk mengetahui apakah data variabel bebas yang digunakan terdistribusi secara normal atau tidak. Hasil korelasi antara indeks vegetasi, umur, dan jumlah tanaman dengan data produksi daun kayu putih menghasilkan nilai $r$ dan $R^{2}$, interpretasi koefisien korelasi ditentukan sesuai dengan pedoman yang ditulis Sugiyono (2014) pada Tabel 2.

Tabel 2.Pedoman interpretasi nilai koefisien korelasi.

\begin{tabular}{cc}
\hline Interval Koefisien & Tingkat Hubungan \\
\hline $0,00-0,199$ & Sangat Lemah \\
$0,20-0,399$ & Lemah \\
$0,4-0,599$ & Sedang \\
$0,6-0,799$ & Kuat \\
$0,8-1,000$ & Sangat Kuat \\
\hline
\end{tabular}

Keterangan : Sugiyono (2014). 
Analisis regresi digunakan untuk memodelkan produksi daun kayu putih menggunakan data penginderaan jauh. Masukan untuk analisis regresi adalah nilai-nilai piksel tanaman kayu putih dari beberapa indeks vegetasi hasil proses LSMA. Peta estimasi produksi daun kayu putih dibuat berdasarkan hasil analisis regresi linier berganda terbaik dari masingmasing indeks vegetasi yang digunakan. Pemilihan model regresi terbaik berdasarkan nilai Standard Error terendah.

Uji akurasi model estimasi dilakukan dengan membandingkan sejumlah data lapangan independen berisi pengukuran daun kayu putih dengan piksel citra yang memuat nilai produksi daun kayu putih hasil estimasi, dan hasilnya dinyatakan dalam SE. Algoritma SE ditunjukkan pada persamaan berikut:

$$
\delta_{\mathrm{est}}=\sqrt{\frac{\left(Y-Y^{\prime}\right)^{2}}{N-2}}
$$

dimana: $\delta_{\text {est }}=$ Standard Error of Estimate

$$
\begin{aligned}
& \mathrm{Y}=\text { Jumlah produksi hasil data lapangan } \\
& \mathrm{Y}^{\prime}=\text { Perkiraan produksi berdasarkan nilai spektral citra } \\
& \mathrm{N}=\text { Jumlah sampel }
\end{aligned}
$$

Sebagai pembanding untuk validasi adalah data produksi dari pabrik minyak kayu putih Balai KPH Yogyakarta. Validasi model dilakukan dengan perhitungan simpangan antara data estimasi produksi dan data produksi pabrik. Persamaan yang digunakan adalah:

$$
\begin{aligned}
& \text { Akurasi }(\%)=100-\left(\left(\frac{\text { Nilai Simpangan }}{\text { Produksi Pabrik }}\right) \times 100\right) \\
& \text { Simpangan }=\text { Estimasi Produksi }- \text { Produksi Pabrik........ }
\end{aligned}
$$

\section{HASIL DAN PEMBAHASAN}

Pemrosesan citra dengan koreksi radiometrik terhadap pengaruh atmosfer dan topografi. Koreksi radiometrik diterapkan pada daerah penelitian sebagai prasyarat proses soft classification LSMA untuk mendapatkan fraksi tanaman kayu putih. Koreksi terhadap pengaruh topografi yang dilakukan akan lebih meningkatkan ketelitian nilai spektral dalam merepresentasikan tanaman kayu putih di lapangan. Hasil menunjukkan bahwa secara visual antara citra sebelum dikoreksi dan setelah dikoreksi pengaruh topografi terlihat perbedaan terutama pada daerah pegunungan dengan kelerengan yang tinggi, demikian juga secara nilai spektral telah mengalami perubahan. Pada Gambar 2 ditunjukkan hasil koreksi radiometrik terhadap pengaruh atmosfer dan topografi citra dengan metode Cosine Correction. 

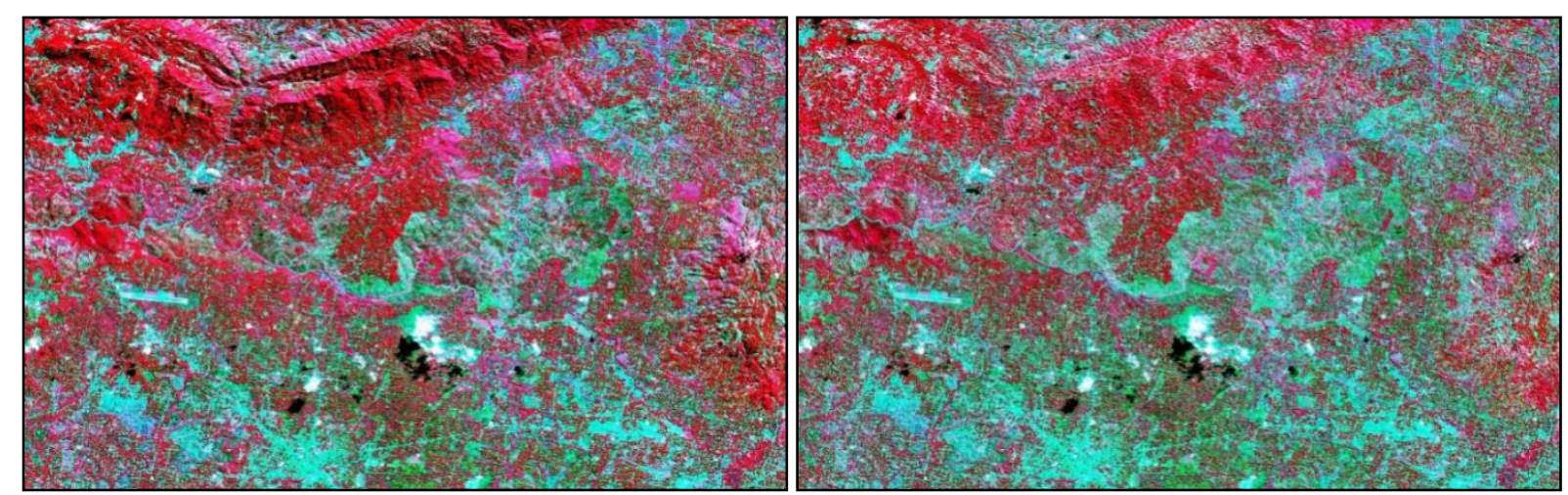

Gambar 2.Kiri: Citra sebelum koreksi. Kanan: Citra setelah koreksi.

Komposit band 843.

\section{Proses Linear Spectral Mixture Analysis (LSMA)}

Hasil dari transformasi MNF memperlihatkan nilai eigenvalue pada masing-masing saluran, melalui Tabel 3 dapat diketahui bahwa MNF 1 menunjukkan nilai eigenvalue paling tinggi sebesar 10,609 dan MNF 10 menunjukkan nilai eigenvalue paling rendah sebesar 0,811. Artinya MNF 1 mempunyai noise lebih sedikit atau mengandung banyak informasi yang diperoleh jika dibandingkan dengan MNF 10 yang menunjukkan semakin berkurangnya kualitas informasi yang diperoleh. Berdasarkan hasil eigenvalue tersebut dapat ditentukan jumlah saluran keluaran yang diinginkan dari transformasi MNF ini. Pada transformasi ini MNF 9 dan 10 tidak dapat digunakan untuk tahapan LSMA selanjutnya karena eigenvalue kurang dari 1, sehingga pada transformasi ini jumlah saluran keluaran yang digunakan sebanyak 8 dari inputnya yaitu 10 saluran.

Tabel 3.Data statistik hasil transformasi MNF.

\begin{tabular}{cccccc}
\hline MNF & Nilai minimum & Nilai maksimum & Rata-rata & Standar Deviasi & Eigenvalue \\
\hline 1 & $-20,002$ & 100,824 & 0,033 & 3,257 & 10,609 \\
2 & $-95,480$ & 58,462 & 0,046 & 2,666 & 7,105 \\
3 & $-51,635$ & 51,565 & 0,044 & 2,256 & 5,087 \\
4 & $-419,245$ & 22,688 & 0,074 & 1,995 & 3,981 \\
5 & $-35,669$ & 180,601 & 0,182 & 1,531 & 2,343 \\
6 & $-53,325$ & 56,495 & 0,228 & 1,324 & 1,753 \\
7 & $-138,832$ & 32,567 & 0,216 & 1,091 & 1,190 \\
8 & $-51,071$ & 255,556 & 0,263 & 1,043 & 1,088 \\
9 & $-337,878$ & 365,514 & 0,175 & 0,985 & 0,970 \\
10 & $-169,526$ & 499,005 & 0,087 & 0,900 & 0,811 \\
\hline
\end{tabular}

Keterangan: Pengolahan citra Sentinel-2A (2018). 
Proses selanjutnya dalam penelitian dengan metode LSMA ini adalah penentuan nilai piksel murni dari setiap endmember menggunakan metode Indeks Kemurnian Piksel (Pixel Purity Index). Input dari tahap ini merupakan citra hasil MNF dengan noise sedikit yang telah dilakukan pada tahap sebelumnya. Cara memperoleh piksel murni dengan cara melakukan iterasi. Pada penelitian ini melakukan iterasi sebesar $10^{4}, 5.10^{4}$, dan $10^{5}$. Citra dengan piksel murni ditunjukkan oleh kecerahan setiap piksel murni yang berhubungan dengan berapa kali terekam sebagai piksel murni.

Berdasarkan beberapa iterasi yang dilakukan memperlihatkan hasil bahwa semakin besar jumlah iterasi yang digunakan maka jumlah piksel murni yang terekam sebagai piksel ekstrim juga semakin banyak, selain itu jumlah iterasi di atas $10^{4}$ akan memberikan hasil yang relatif sama atau tidak jauh berbeda. Hasil iterasi yang dipilih untuk penentuan endmember pada penelitian ini adalah iterasi $10^{4}$.

Piksel hasil proses PPI yang cerah dan hitungan iterasi yang paling tinggi adalah kandidat endmember. Endmember merupakan objek atau material yang akan dipisahkan pada setiap piksel. Jumlah endmember yang digunakan untuk klasifikasi dengan metode LSMA tidak boleh lebih dari jumlah saluran yang digunakan. Penelitian ini menggunakan 9 band yaitu band green (3), red (4), red-edge $(5,6,7)$, NIR (8), narrow NIR (8A), dan $\operatorname{SWIR}(11,12)$, sedangkan jumlah endmember ditentukan sebanyak 4 endmember yaitu kayu putih, vegetasi non-kayu putih, lapisan kedap air, dan lahan terbuka. Pemilihan keempat endmember dengan melihat kondisi tutupan lahan di daerah penelitian secara umum yang dianggap telah mewakili sebagian besar jenis tutupan lahan yang ada.

Idealnya nilai persentase yang dihasilkan oleh setiap endmember mempunyai rentang nilai antara 0 sampai dengan 1 , sehingga jumlah persentase pada setiap piksel harus sama dengan jumlah persentase setiap endmember pada piksel tersebut yaitu sebesar 1 atau 100\%. Secara statistik hasil LSMA pada penelitian ini terdapat nilai minus dan lebih dari satu. Hal tersebut dikarenakan objek yang terdapat di kawasan hutan kayu putih tidak terbatas pada empat endmember yang digunakan pada penelitian ini yang juga mempunyai karakteristik spektral sendiri. Setiap kelas endmember mempunyai kurva pantulan pada setiap panjang gelombang. Pada Gambar 3 menunjukkan pantulan spektral keempat endmember mengalami peningkatan sampai panjang gelombang red-edge dan mengalami penurunan pada panjang gelombang NIR kemudian meningkat kembali pada panjang gelombang narrow NIR. 


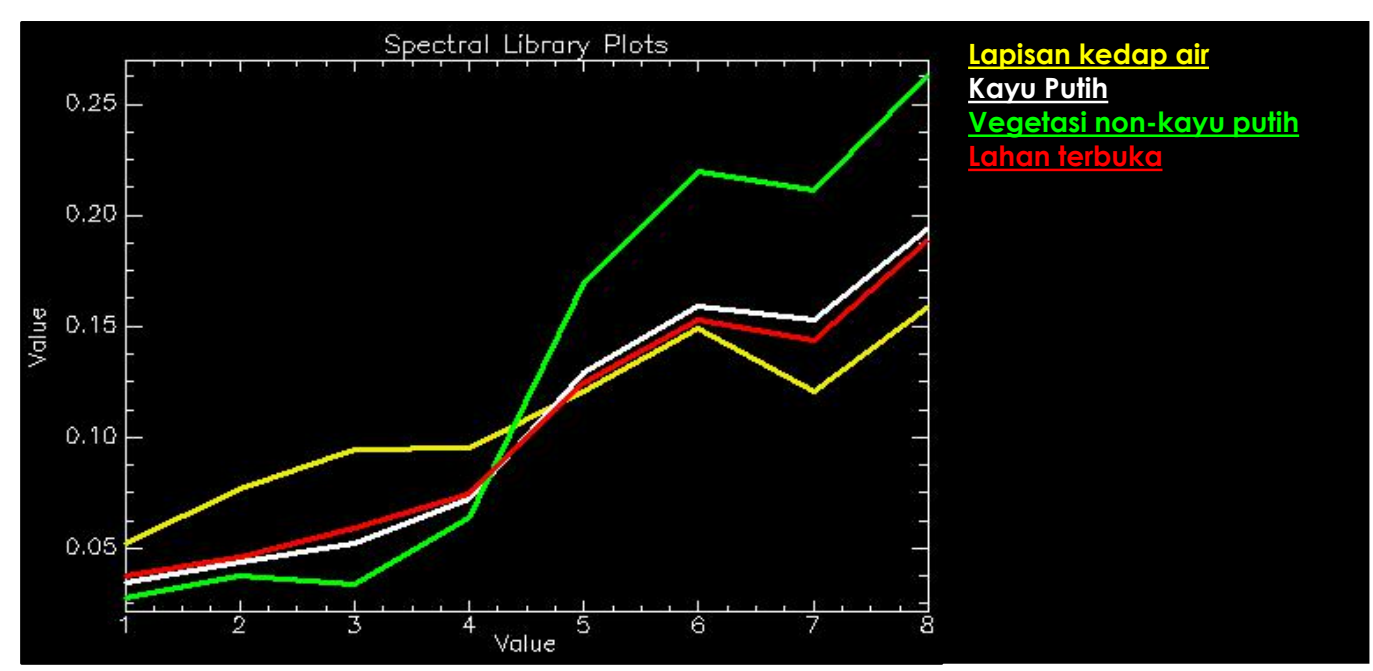

Gambar 3.Kurva pantulan spektral endmember.

Tanaman kayu putih mempunyai pantulan spektral tinggi pada panjang gelombang green, red-edge, dan narrow NIR. Kenampakan itu menunjukkan bahwa pantulan daun pada beberapa lapis dikontrol oleh struktur internal daun. Pada panjang gelombang visible kurva pantulan kayu putih lebih tinggi daripada vegetasi non-kayu putih dan lebih mendekati kurva pantulan lahan terbuka, kenampakan ini disebabkan sebagian lahan yang ditanami kayu putih dimanfaatkan untuk tumpangsari sehingga memberi pengaruh pantulan spekral pada tanaman kayu putih. Struktur daun kayu putih yang kecil menyebabkan kerapatan tajuknya memiliki rongga yang dapat meneruskan energi matahari sehingga mempengaruhi pantulan spekral.

Hasil klasifikasi metode LSMA berupa citra fraksi dari setiap endmember tutupan lahan bersama dengan citra RMS Error-nya seperti yang ditunjukkan pada Gambar 4. Hasil klasifikasi LSMA yang diperoleh memiliki nilai RMS Error minimum sebesar 0,000 dan ratarata sebesar 0,006. Hasil tersebut menunjukkan bahwa metode LSMA mempunyai standar deviasi kesalahan yang kecil sehingga mampu mengklasifikasikan tutupan lahan dengan baik, serta nilai fraksi setiap endmember apabila dijumlahkan akan menghasilkan nilai sama dengan satu sehingga hasilnya dapat diandalkan. Kemampuan metode LSMA secara kuantitatif dapat memberikan informasi persentase setiap endmember tutupan lahan pada setiap piksel menjadikan metode ini sebagai salah satu metode klasifikasi yang akurat. 


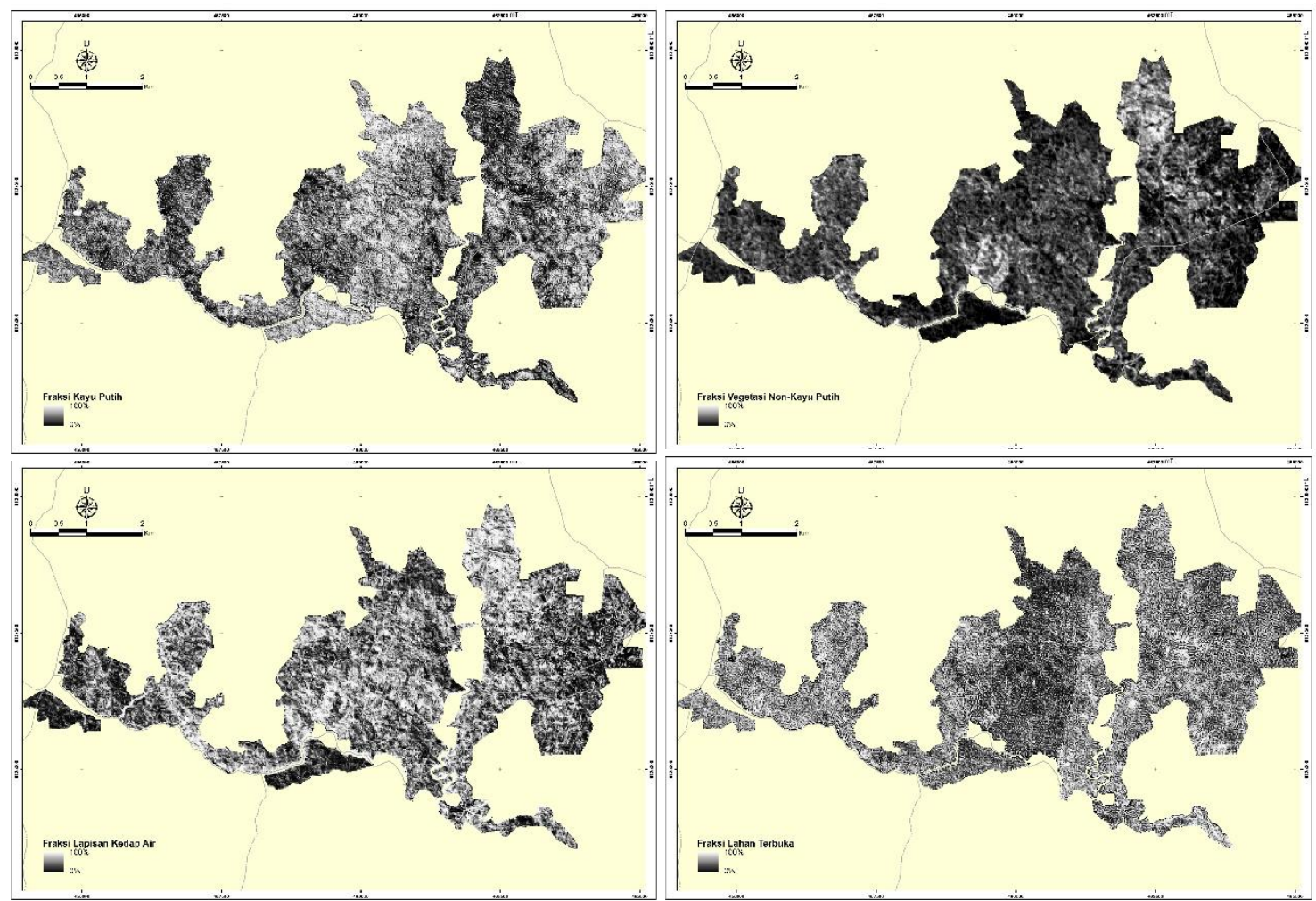

Gambar 4. Persentase setiap fraksi endmember.

Metode yang digunakan untuk menguji akurasi persentase fraksi adalah Mean Absolute Error (MAE). Hasil persentase fraksi dibandingkan dengan citra Google Earth. Hasil analisis uji akurasi menunjukkan akurasi yang sangat baik, yaitu sebesar 99,66\%. Hal ini menunjukkan bahwa metode LSMA mampu mengklasifikasikan setiap objek tutupan lahan pada satu piksel resolusi $20 \mathrm{~m}$ citra Sentinel-2A dengan baik sehingga diperoleh persentase tutupan kayu putih pada setiap piksel untuk proses selanjutnya.

\section{Analisis statistik}

Hasil pengukuran umur, jumlah tanaman, dan produksi daun kayu putih pada 60 plot sampel diperoleh umur tanaman menunjukkan rentang nilai antara 10-48 tahun (rerata=30 tahun, standar deviasi=9,02), jumlah tanaman berkisar antara 525-1.050 pohon/hektar (rerata $=734$ pohon/hektar, standar deviasi $=121,68$ ), dan produksi daun kayu putih berkisar antara $0,405-1,704$ ton/hektar (rerata=1,066 ton/hektar, standar deviasi=0,32).

Hasil uji korelasi dan regresi beberapa indeks vegetasi kayu putih, umur, jumlah tanaman terhadap produksi daun kayu putih disajikan pada Tabel 4. Hasil uji korelasi dan regresi tertinggi pada penggunaan indeks vegetasi kayu putih MERIS Terrestrial Chlorophyll Index (MTCI) dan hasil uji korelasi dan regresi terendah pada penggunaan indeks vegetasi 
kayu putih Normalized Difference Infrared Index (NDII). Model regresi terbaik adalah persamaan estimasi produksi berdasarkan penggunaan indeks vegetasi kayu putih MTCI yang memiliki nilai $r$ terbesar dan SE terkecil yang selanjutnya digunakan untuk membuat model estimasi produksi dengan rumus regresi yaitu:

$$
y=1,128-0,022 x_{1}+0,001 x_{2}-0,005 x_{3}
$$

Tabel 4.Hasil korelasi dan regresi indeks vegetasi, umur, dan jumlah tanaman terhadap produksi daun kayu putih.

\begin{tabular}{ccccccc}
\hline No & Input & Normalitas Data & Model Regresi & $r$ & $R^{2}$ & SE \\
\hline 1 & SR Red-Edge & Normal & Linier Berganda & 0,667 & 0,445 & 0,186 \\
2 & CI Red-Edge & Normal & Linier Berganda & 0,668 & 0,446 & 0,186 \\
3 & CI Green & Normal & Linier Berganda & 0,666 & 0,444 & 0,186 \\
4 & MTCI & Normal & Linier Berganda & 0,668 & 0,447 & 0,183 \\
5 & Red-Edge NDVI & Normal & Linier Berganda & 0,667 & 0,445 & 0,185 \\
6 & OSAVI & Normal & Linier Berganda & 0,667 & 0,445 & 0,185 \\
7 & MSI & Normal & Linier Berganda & 0,667 & 0,445 & 0,185 \\
8 & NDII & Normal & Linier Berganda & 0,664 & 0,441 & 0,186 \\
\hline
\end{tabular}

Keterangan : Pengolahan data (2018).

Hasil uji korelasi dan regresi tertinggi pada indeks vegetasi kayu putih MTCI yang menggunakan band red, red-edge, dan NIR memberikan nilai yang kuat terhadap produksi, hal tersebut disebabkan MTCI yang memanfaatkan band-band tersebut menggambarkan kandungan klorofil pada tutupan vegetasi sehingga mampu memberikan gambaran terhadap produksi.

Hasil analisis regresi terendah pada indeks vegetasi kayu putih NDII yang menggunakan band NIR dan SWIR tetap memberikan korelasi kuat terhadap produksi. Secara teori band NIR dan SWIR merupakan panjang gelombang yang peka terhadap vegetasi. Sifat spektral vegetasi pada band NIR dan SWIR lebih banyak dipengaruhi oleh struktur sel daun dan kandungan air pada daun. Pada band NIR vegetasi hijau sehat ditandai dengan pantulan sangat tinggi, transmisi sangat tinggi, dan penyerapan sangat rendah. Respon spektral vegetasi pada band SWIR didominasi oleh saluran penyerapan air. Jika kelembaban daun menurun, pantulan pada panjang gelombang SWIR meningkat tajam. Pada band SWIR total kelembaban vegetasi mengontrol pantulan dengan banyak energi diserap oleh air di daun.

Rendahnya korelasi dapat disebabkan kondisi tanaman kayu putih yang sebagian besar berumur diatas 30 tahun yang memiliki kesehatan kurang baik, ditunjukkan dengan warna 
daun kekuningan. Struktur daun kayu putih yang kecil dan tidak sehat dapat mempengaruhi pantulan spektral daun kayu putih pada panjang gelombang NIR dan SWIR karena struktur daun dan kelembabanya tidak seperti pada vegetasi hijau yang sehat. Tanaman kayu putih akan menyerap energi lebih sedikit dan memantulkan energi lebih tinggi terutama pada spektrum merah, oleh karena itu indeks vegetasi kayu putih MTCI yang memakai band red dan red-edge mempunyai korelasi lebih tinggi.

\section{Estimasi produksi daun kayu putih}

Hasil estimasi produksi daun kayu putih menggunakan 8 indeks vegetasi kayu putih hasil proses LSMA citra Sentinel-2A disajikan pada Tabel 5.

Tabel 5.Hasil estimasi produksi daun kayu putih dari tiap indeks vegetasi kayu putih.

\begin{tabular}{llccc}
\hline \multirow{2}{*}{ No } & \multicolumn{1}{c}{ Input } & \multicolumn{3}{c}{ Estimasi Produksi (ton/ha/tahun) } \\
& & minimum & maksimum & total \\
\hline 1 & SR Red-Edge & 0,228 & 1,801 & $2.378,004$ \\
2 & CI Red-Edge & 0,225 & 1,805 & $2.379,400$ \\
3 & CI Green & 0,235 & 1,759 & $2.375,510$ \\
4 & MTCI & 0,210 & 1,772 & $2.385,550$ \\
5 & Red-Edge NDVI & 0,227 & 1,801 & $2.377,203$ \\
6 & OSAVI & 0,236 & 1,765 & $2.375,692$ \\
7 & MSI & 0,234 & 1,769 & $2.378,788$ \\
8 & NDII & 0,255 & 1,725 & $2.361,735$ \\
\hline
\end{tabular}

Keterangan : Pengolahan data (2018).

Proses reklasifikasi yang dilakukan akan menghasilkan rentang nilai produksi sesuai dengan jumlah pikselnya. Berdasarkan nilai produksi dan jumlah piksel (dimana setiap piksel memiliki luas $400 \mathrm{~m}^{2}$ ) maka dapat diperoleh nilai rata-rata produksi daun kayu putih per hektar, sehingga total estimasi produksi pada kawasan hutan tanaman kayu putih dapat juga diketahui. Selanjutnya dilakukan uji akurasi model estimasi dan hasilnya dapat dilihat pada Gambar 5. Hasil uji akurasi model tersebut menunjukkan bahwa akurasi tertinggi dihasilkan dengan model menggunakan indeks vegetasi MTCI. 


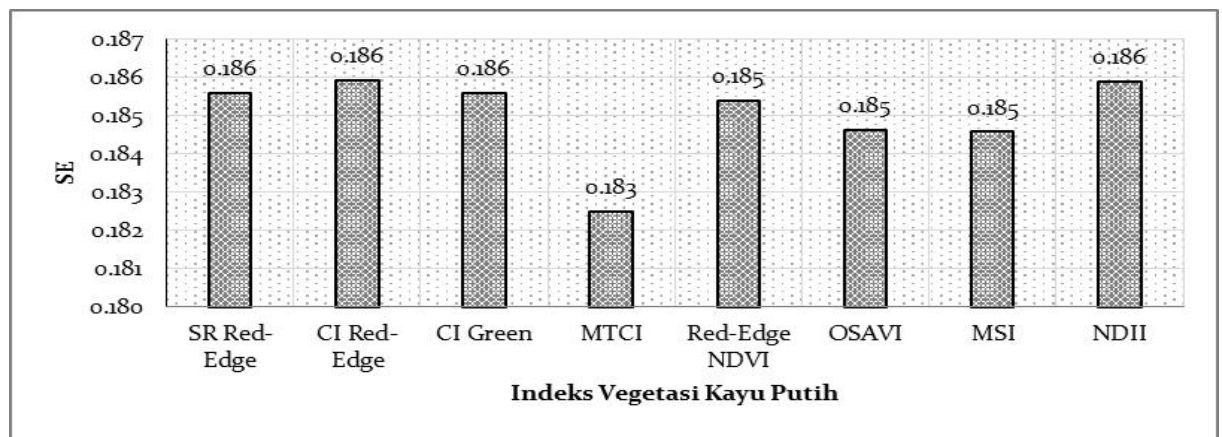

Gambar 5.Hasil uji akurasi estimasi produksi daun kayu putih.

Sebagai pembanding untuk validasi adalah data produksi dari pabrik minyak kayu putih Balai KPH Yogyakarta. Validasi model dilakukan dengan perhitungan simpangan antara data estimasi produksi dan data produksi pabrik. Persamaan yang digunakan adalah:

$$
\text { Akurasi }(\%)=100-\left(\left(\frac{\text { Nilai Simpangan }}{\text { Produksi Pabrik }}\right) x \text { 100 }\right)
$$

Simpangan $=$ Estimasi Produksi - Produksi Pabrik

Berdasarkan perhitungan menggunakan persamaan tersebut diperoleh akurasi estimasi produksi antara 75,68\% - 76,44\%. Akurasi tertinggi sebesar 76,44 pada indeks vegetasi kayu putih MTCI dan terendah sebesar 75,68\% pada indeks vegetasi NDII. Hasil estimasi menggunakan 8 indeks vegetasi kayu putih hasil proses LSMA disajikan pada Tabel 6. Hasil tersebut underestimate dibandingkan dengan data produksi pabrik sebesar 3.120,75 ton. Hasil estimasi underestimate disebabkan oleh perbedaan waktu perekaman citra dengan waktu dimulainya pemanenan daun dan karena adanya pengulangan pemanenan daun.

Tabel 6.Akurasi hasil estimasi produksi daun kayu putih terhadap produksi riil bulan JuniDesember 2017.

\begin{tabular}{cccccc}
\hline No & Input & $\begin{array}{c}\text { Estimasi Produksi } \\
\text { (ton/tahun) }\end{array}$ & $\begin{array}{c}\text { Produksi Pabrik } \\
\text { (ton/tahun) }\end{array}$ & $\begin{array}{c}\text { Simpangan } \\
\text { (ton) }\end{array}$ & Akurasi (\%) \\
\hline 1 & SR Red-Edge & $2.378,004$ & $3.120,750$ & 742,746 & 76,20 \\
2 & CI Red-Edge & $2.379,400$ & $3.120,750$ & 741,350 & 76,24 \\
3 & CI Green & $2.375,510$ & $3.120,750$ & 745,240 & 76,12 \\
4 & MTCI & $2.385,550$ & $3.120,750$ & 735,200 & 76,44 \\
5 & Red-Edge NDVI & $2.377,203$ & $3.120,750$ & 743,547 & 76,17 \\
6 & OSAVI & $2.375,692$ & $3.120,750$ & 745,058 & 76,13 \\
7 & MSI & $2.378,788$ & $3.120,750$ & 741,962 & 76,22 \\
8 & NDII & $2.361,735$ & $3.120,750$ & 759,015 & 75,68 \\
\hline
\end{tabular}

Keterangan : Pengolahan data (2018). 
Waktu perekaman citra yang digunakan untuk penelitian bulan Juni tidak bersamaan dengan waktu dimulainya pemangkasan daun kayu putih yaitu pada bulan April. Hal tersebut menyebabkan adanya sebagian area pada citra yang sudah dilakukan pemanenan. Jika dilakukan pengurangan produksi daun pada bulan April dan Mei sebesar 291,43 ton (data produksi per bulan BKPH Yogyakarta) terhadap data pabrik selama setahun maka akan diperoleh data produksi bulan Juni-Desember sebesar 2.829,32 ton. Berdasarkan data produksi tersebut dapat diketahui nilai akurasinya meningkat yaitu 83,47\% - 84,32\% meskipun hasil estimasi tetap underestimate. Korelasi antara produksi di lapangan dan hasil estimasi produksi menunjukkan hubungan yang kuat. Korelasi tertinggi ditunjukkan antara produksi di lapangan dan hasil estimasi produksi yang menggunakan variabel indeks vegetasi kayu putih MTCI yang dapat dilihat pada Gambar 6.

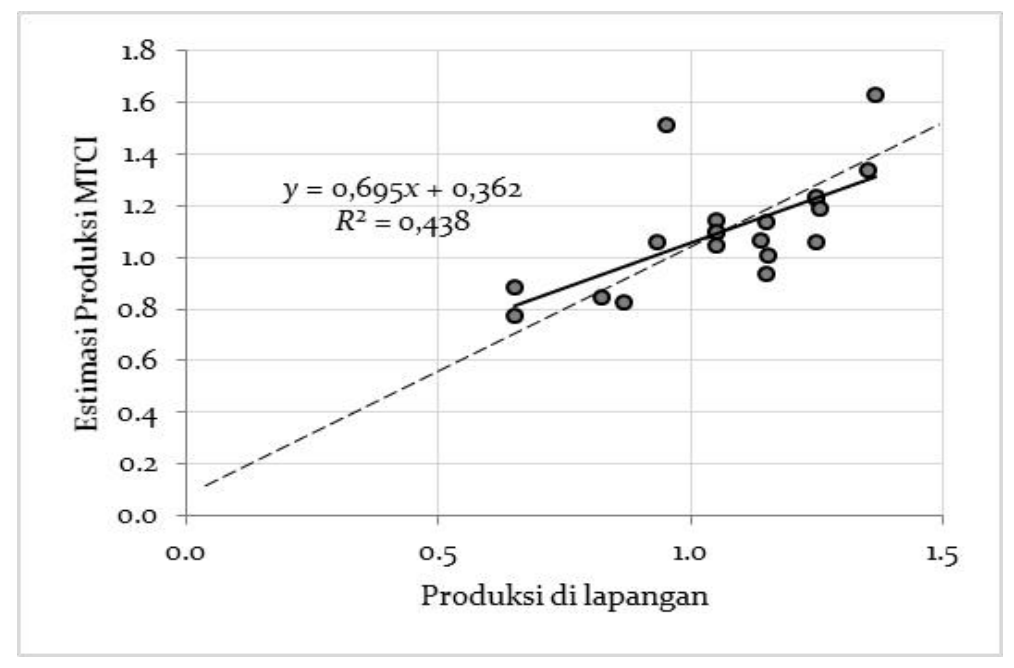

Gambar 6. Grafik hubungan hasil estimasi produksi dengan produksi di lapangan.

Peta hasil estimasi produksi daun kayu putih pada lokasi penelitian dibuat berdasarkan persamaan model regresi terbaik yang digunakan pada perhitungan estimasi produksi yaitu model regresi berganda dengan variabel bebas umur, jumlah tanaman dan indeks vegetasi kayu putih MTCI seperti ditunjukkan pada Gambar 7. Persebaran umur tanaman kayu putih yang mengelompok pada blok-blok tertentu dan kurang teratur di dalam kawasan hutan memberikan pengaruh terhadap peta persebaran estimasi produksinya. Persebaran produksi tiap piksel menjadi mengelompok pada blok umur tertentu karena variabel umur tanaman memberikan pengaruh yang lebih tinggi dibandingkan variabel indeks vegetasi kayu putih ataupun jumlah tanaman. Pengaruh umur tanaman terhadap hasil produksi di lapangan dan hasil estimasi produksi dianalisis pada hubungan umur terhadap produktivitas tanaman kayu putih untuk mengetahui umur optimal tanaman kayu putih dalam memproduksi daun. 


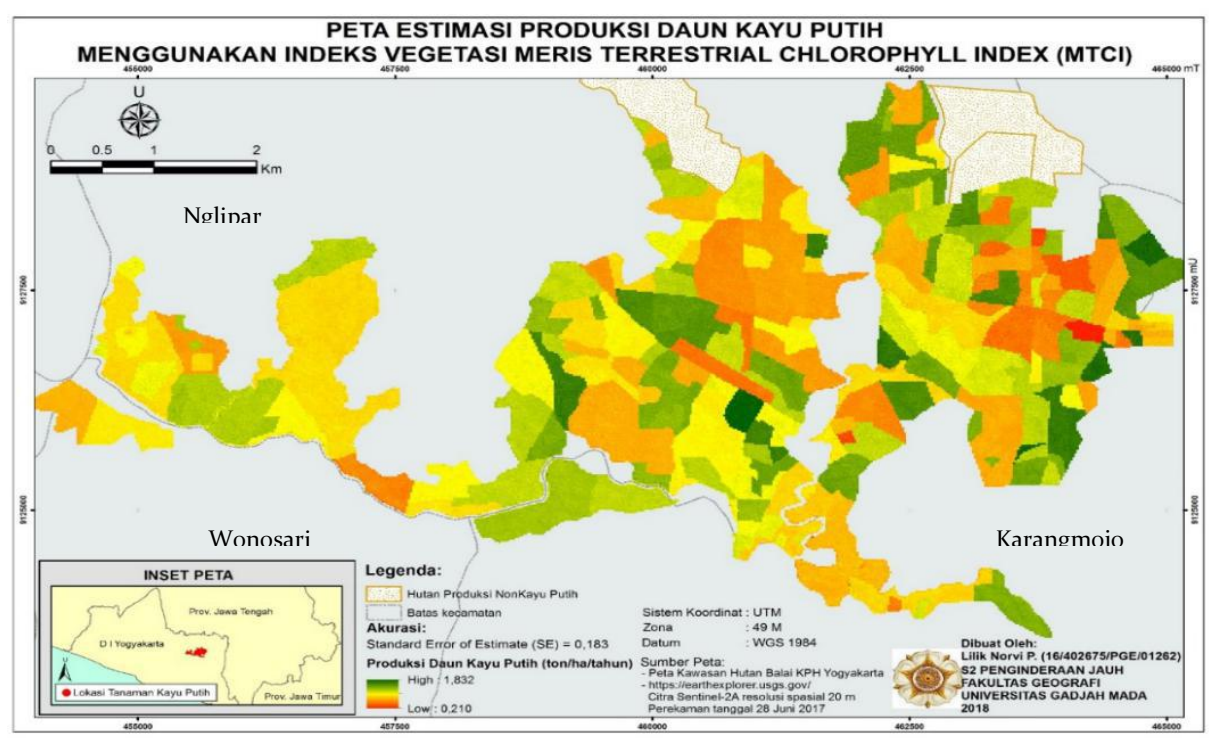

Gambar 7. Peta estimasi produksi daun kayu putih.

\section{KESIMPULAN}

Citra Sentinel-2A dapat digunakan untuk mengestimasi produksi daun kayu putih melalui model regresi linier berganda antara faktor vegetatif (umur dan jumlah tanaman) dan indeks vegetasi terhadap produksi. Penggunaan metode Linear Spectral Mixture Analysis dengan akurasi 99,66\% mampu menentukan persentase fraksi tanaman kayu putih, vegetasi non-kayu putih, lapisan kedap air, dan lahan terbuka sehingga penggunaan indeks vegetasi berdasarkan fraksi kayu putih menjadi lebih akurat. Keluaran proses LSMA yang kurang ideal dapat terjadi mengingat bahwa pada daerah kajian memiliki tutupan lahan yang beragam, tidak hanya terdiri atas objek kayu putih, vegetasi non-kayu putih, lapisan kedap air, dan lahan terbuka, namun masih terdapat unsur-unsur tutupan lahan lainnya yang kemudian terklasifikasi menjadi empat endmember tersebut. Semua indeks vegetasi kayu putih yang digunakan secara simultan dengan umur dan jenis tanaman memiliki korelasi signifikan terhadap produksi daun kayu putih di lokasi penelitian. Nilai korelasi tertinggi pada penggunaan indeks vegetasi kayu putih MTCI dengan nilai $r=0,668$.

Peta estimasi produksi daun kayu putih di lokasi penelitian berdasarkan model regresi linier berganda dengan variabel umur, jumlah tanaman, dan indeks vegetasi kayu putih MTCI. Model persamaan regresinya adalah $y=1,128-0,022 x_{1}+0,001 x_{2}-0,005 x_{3}$ memiliki akurasi tertinggi dibandingkan indeks vegetasi lain yang digunakan dalam penelitian dengan nilai SE $=0,183$. Keunggulan indeks vegetasi MTCI adalah memanfaatkan band red, red-edge, dan NIR yang terbukti dari penelitian sebelumnya lebih sensitif terhadap kandungan klorofil dan biomassa tanaman. Hasil perbandingan antara data produksi pabrik dengan hasil estimasi 
produksi yang menggunakan indeks vegetasi pada penelitian ini adalah underestimate. Estimasi dengan indeks vegetasi MTCI diperoleh produksi 0,210-1,772 ton/ha/tahun. Berdasarkan perhitungan menggunakan simpangan dan validasi data pabrik, akurasi pada indeks vegetasi MTCI sebesar 76,44\% dengan estimasi produksi sebesar 2.385,550 ton.

\section{UCAPAN TERIMA KASIH}

Kami mengucapkan terima kasih kepada Gubernur DIY, Pemda DIY, dan Kepala Dinas Kehutanan dan Perkebunan DIY yang telah memberi kesempatan untuk melanjutkan jenjang pendidikan S2 di Program Studi S2 Penginderaan Jauh, Fakultas Geografi, UGM. Pada kesempatan ini kami juga mengucapkan terima kasih kepada Dr. Projo Danoedoro, M.Sc., dan Dr. Pramaditya Wicaksono, M.Sc., Dr. Retnadi Heru Jatmiko, M.Sc., dan Dr. Prima Widayani, M.Si., dan para dosen pengajar yang selama ini telah membagi ilmu selama perkuliahan berlangsung. Penulis juga mengucapkan banyak terima kasih kepada Balai KPH Yogyakarta atas data penelitian serta USGS pada website https://earthexplorer.usgs.gov/ dan Google Earth Pro yang telah menyediakan data citra Sentinel-2A, DEM ALOS Palsar dan Google Earth pada lokasi penelitian.

\section{DAFTAR PUSTAKA}

Asis, A. M. De and K. Omasa. (2007). Estimation of vegetation parameter for modeling soil erodion using Linear Spectral Mixture Analysis of Landsat ETM data.Photogrammetry and Remote Sensing. 62, pp. 309-324.

Badan Standarisasi Nasional. (2011). SNI 7724:2011; Pengukuran dan penghitungan cadangan karbon - Pengukuran lapangan untuk penaksiran cadangan karbon hutan. Badan Standarisasi Nasional. Jakarta.

Brown, D. G. (2001). A Spectral Unmixing Approach to Leaf Area Index (LAI) Estimation at The Alpine Treeline Ecotone. Dalam A. C. Millington, S. J. Walsh, and A. E. Osborne, editor.GIS and Remote Sensing Applications in Biogeography and Ecology. Springer US.

Chavez, P. S. (1996). Image-based atmospheric corrections-revisited and improved. Photogrammetric Engineering \& Remote Sensing. 62 (9), pp. 1025-1036. 
Clevers, J. G. P. W. and A. A. Gitelson. (2013). Remote estimation of crop and grass chlorophyll and nitrogen content using Red-Edge bands on Sentinel-2 and 3. International Journal of Applied Earth Observation and Geoinformation. 23, pp. 344-351.

Dash, J. and P. J. Curran. (2004). The MERIS Terrestrial Chlorophyll Index. International Journal of Remote Sensing. 25, pp. 5403-5413.

Daughtry, C. S., C. L. Walthall, M. S. Kim, E. Brown De Colstoun, and J. E. McMurtrey. (2000). Estimating corn leaf chlorophyll concentration from leaf and canopy reflectance. Remote Sensing of Environment. 74, pp. 229-239.

Delegido, J., J. Verrelst, L. Alonso, and J. Moreno. (2011). Evaluation of Sentinel-2 Red Edge bands for empirical estimation of green LAI and chlorophyll content. Sensor. 11, pp.70637081.

Dong, T., J. Meng, J. Shang, J. Liu, ang B. Wu. (2015). Evaluation of chlorophyll-related vegetation indices using simulated Sentinel-2 data for estimation of crop fraction of absorbed photosynthetically active radiation. IEEE Journal. pp. 1939-1404.

Europen Space Agency. (2015). Sentinel-2 User Handbook. Hlm. 42-50. Paris.

Fauziana, F. (2016). Pemodelan Spasial Citra SPOT 7 untuk Estimasi Produksi Pucuk Teh (Camellia sinensis (L). O. Kuntze) di Perkebunan Teh PT Pagilaran Kabupaten Batang, Jawa Tengah. Tesis(Tidak dipublikasikan). Program Studi Penginderaan Jauh, Fakultas Geografi, Universitas Gadjah Mada, Yogyakarta.

Fernandez-Manso, A, O. Fernandez-Manso, and C. Quintano. (2016). Sentinel-2A Red Edge spectral indices suitability for discriminating burn severity. International Journal of Applied Earth Observation and Geoinformation. 50, pp. 170-175.

Frampton, W. J., J. Dash, G. Watmough, and E. J. Milton. (2013). Evaluating the capabilities of Sentinel-2 for quantitative estimation of biophysical variables in vegetation. ISPRS Journal of Photogrammetry and Remote Sensing. 82, pp. 83-92. 
Gitelson, A. A. and M. N. Merzlyak. (1994). Spectral Reflectance Changes Associated with Autumn Senescence of Aesculus hippocastanum L. and Acer platanoides L. Leaves. Spectral Features and Relation to Chlorophyll Estimation. Journal Plant Physiol. 143, pp. 286-292.

Gitelson, A. A., Y. Gritz, and M. N. Merzlyak. (2003). Relationships between Leaf Chlorophyll Content and Spectral Reflectance and Algorithms for Non-Destructive Chlorophyll Assessment in Higher Plant Leaves. Journal Plant Physiol. 160, pp. 271-282.

Haboudane, D., J. R. Miller, N. Tremblay, P. J. Zarco-Tejadad, and L. Dextrazec. (2002). Integrated narrow-band vegetation indices for prediction of crop chlorophyll content for application to precision agriculture. Remote Sensing of Environment. 81, pp. 416-426.

Hardisky M. A., R. M. Smart, and V. Klemas. (1983). Growth Response and Spectral Characteristics of a Short Spartina altemiflora Salt Marsh Irrigated with Freshwater and Sewage Effluent. Remote Sensing of Environment. 13, pp. 57-67.

Howard, J.A. (1996). Penginderaan Jauh untuk Sumberdaya Hutan Teori dan Aplikasi. Hlm. 12. Hartono, Dulbahri, Suharyadi, P. Danoedoro, R. H. Jatmiko, penerjemah. Sutanto, penyunting. Gadjah Mada University Press, Yogyakarta.

Immitzer, M., F. Vuolo, and C. Atzberger. (2016). First experience with Sentinel-2 data for crop and tree species classifications in central Europe. Remote Sensing. 8, pp. 166.

Kartikawati, N. K., A. Rimbawanto, M. Susanto, L. Baskorowati, dan Prastyono. (2014). Budidaya dan Prospek Pengembangan Kayu Putih (Melaleuca cajuputi). Hlm. 23. IPB Press, Bogor.

Klein, A. G. and B. L. Isacks. (1999). Spectral mixture analysis of Landsat Thematic Mapper images applied to the detection of the transient snowline on tropical Andean glaciers. Global and Planetary Change. 22: 139-154. 
Murti, S. H. (2014). Permodelan Spasial Untuk Estimasi Produksi Padi Dan Tembakau Berdasarkan Citra Multiresolusi (Kasus untuk Produksi Padi di Kabupaten Wonosobo dan Sragen, serta Produksi Tembakau di Kabupaten Temanggung, Provinsi Jawa Tengah). Disertasi (Tidak dipublikasikan). Minat Studi Penginderaan Jauh, Program Studi Ilmu Geografi, Fakultas Geografi, Universitas Gadjah Mada, Yogyakarta.

Purwadhi, F. S. H. dan T. B. Santoso. (2009). Pengantar Interpretasi Citra Penginderaan Jauh.Edisi kedua, Lembaga Penerbangan dan Antariksa Nasional dan Universitas Negeri Semarang.

Qi, J., A. R. Huete, M. S. Moran, A. Chaehbouni, and R. D. Jackson. (1993). Intepretation of vegetation indices derived from multi-temporal SPOT images. Remote Sensing of Environment. 44, pp. 89-101.

Richter, K., T. B. Hank, F. Vuolo, W. Mauser, and G. D’Urso. (2012). Optimal exploitation of the Sentinel-2 spectral capabilities for crop leaf area index mapping. Remote Sensing. 4, pp. $561-582$.

Rock B, N., J. E. Vogelmann, D. L. Williams, A. F. Vogelmann, and T. Hoshizaki. (1986). Remote Detection of Forest Damage. Plant Responses to Stress May have Spectral "Signatures" that Could be Used to Map, Monitor, and Measure Forest Damage. Bio Science. 36, pp. 439-445.

Rondeaux, G., M. Steven, and F. Baret. (1996). Optimization of Soil-Adjusted Vegetation Indices. Remote Sensing Environment. 55, pp. 95-107.

Soerianegara, I. dan A. Indrawan. (1988). Ekologi Hutan Indonesia. Laboratorium Ekologi Hutan, Fakultas Kehutanan, Institut Pertanian Bogor, Bogor.

Somers, B., Asner, P. Gregory, L. Tits, and P. Coppin. (2011). Endmember variability in Spectral Mixture Analysis: Areview. Remote Sensing of Environment. 115 (7), pp. $1603-$ 1616.

Sugiyono. (2014). Statistik untuk Penelitian. Alfabeta, Bandung. 
Teillet, P. M., B. Guindon and D. G. Goodenough. (1982). On the slope-aspect correction of multispectral scanner data. Canadian Journal of Remote Sensing. 8 (2), pp. 84-106.

Vanclay, J. K. (1995). Growth model for tropical forest: A synthesis of models and methods. Forest Science. 41 (1), pp. 7-42.

Wiratmoko, D. (2014). Penggunaan Citra Worldview-2 Untuk Estimasi Produksi Kelapa Sawit (Elaeis guineensis Jacq.) Sebagai Implementasi Pertanian Presisi (Studi di Unit Kebun Adolina, PT. Perkebunan Nusantara IV Kabupaten Serdang Bedagai, Provinsi Sumatera Utara). Tesis (Tidak dipublikasikan). Program Studi Penginderaan Jauh, Fakultas Geografi, Universitas Gadjah Mada, Yogyakarta.

Wójtowicz, M., A. Wójtowicz, and J. Piekarczyk. (2016). Application of remote sensing methods in agriculture. Communications in Biometry and Crop Science. 11 (1), pp. 31-50. 